\title{
Electrophoretic Analysis of Serum Proteins in Cystic Fibrosis
}

\author{
JOHN M. THOMAS, A. DONALD MERRITT, AND M. E. HODES ${ }^{(6)}$ \\ Department of Medical Genetics, Indiana University Medical Center, Indianapolis, Indiana, USA
}

\begin{abstract}
Summary
This study utilized isoelectric focusing and electrophoresis in an attempt to detect a cystic fibrosis (CF) serum factor(s), for which there is considerable indirect evidence. The method of isoelectric focusing in polyacrylamide gels (IEFAG) specified by Wilson et al. (53), as reproduced in our laboratory, did not enable the detection of a CF factor protein reported to focus near pH 8.4-8.5. Consequently, we employed our modified IEFAG techniques, which enabled us to demonstrate significantly enhanced resolution and striking heterogeneity in serum $\gamma$-globulins. Despite the significant increase in the number of bands resolved by our methods, neither a difference at pH 8.48.5 nor other differences throughout the alkaline pH range could be detected consistently in the CF and heterozygous sera. The two-step IEFAG/disc electrophoresis technique outlined by Altland et al. (2), as reproduced in our laboratory, indicated that at least one small, cationic protein could be fractionated from all serum samples. Improvements in the method of disc electrophoresis resulted in the observation of numerous bands from some samples and of differences among the samples, but no protein band unique to the CF genotypes was observed.

Our approach, employing different electrophoretic techniques and varying the conditions of sample analysis, should have increased the likelihood of detecting a protein or proteins specific for the CF genotypes. Despite the many variations in our approach, no consistently unique protein was observed in the CF or heterozygous sera.
\end{abstract}

\section{Speculation}

A CF serum factor cannot be readily demonstrated by the electrophoretic techniques described. The value of the "biophysical assay" and the "nonbiologic technique" reported in the literature is suspect, and the promise and applicability of these techniques as diagnostic tests for the $\mathbf{C F}$ gene should be carefully evaluated.

Cystic fibrosis is the most common inherited disease among Caucasians $(14,30)$. Although the mode of inheritance has been recognized as autosomal recessive for several years $(16,18$, 56), the primary genetic defect remains unknown $(11,13,19$, 26). In-addition, a reliable, reproducible assay for detecting the $\mathrm{CF}$ gene product in the homozygous or heterozygous state is not yet available, despite many promising leads $(11,19,27,30$, 38).

Most investigations relative to the basic defect have centered on a putative factor or factors present in fluids or elaborated by cells from $C F$ patients and obligate heterozygotes $(11,26,27)$. The study of biologic fluids using experimental systems has suggested two general categories for these factors: (1) factors affecting ciliary mobility, and (2) factors influencing membrane transport (19). The ciliary bioassays, in particular, have been used extensively as research tools enabling the partial purification and characterization of protein factors which may be rele- vant to the pathogenesis of $\mathrm{CF}(8,9)$. The evidence from these investigations suggests that the factor is a heat-labile protein with a molecular weight of $1,000-10,000$ and that the protein appears to bind to $\lg (4,5,7,10,15,17)$.

Isoelectric focusing (IEF) has been used by two groups of investigators to obtain serum fractions with activity against ciliated preparations. In 1972 Schmoyer et al. $(36,37)$ reported that a scrum factor, responsible for ciliary asynchrony in oyster gill preparations, could be prepared from pooled CF heterozygous sera by ion exchange chromatography and IEF, and that their purified preparations had an isoelectric point of 8.54 (indicating a cationic molecule in the $\gamma$-globulin fraction). In the following year, Barnett et al. (6) fractionated sera from a CF homozygote and heterozygote by ion exchange chromatography and IEF. The fraction which inhibited cilia was predominantly associated with $\mathrm{IgGl}$ and was within a narrow band that focused at $\mathrm{pH} 9.1-9.3$ (6), more than half of one $\mathrm{pH}$ unit above Schmoyer's active fraction $(55,56)$.

In view of considerable evidence for a unique factor or factors in CF fluids, the identification of the factor(s) as a protein band(s) by electrophoretic analysis should be possible. In 1973 Wilson et al. (54) reported the demonstration of serum protein differences in CF by IEFAG, a relatively new technique which appears to offer improved resolving power over traditional electrophoretic techniques (21). Wilson et al. (54) observed a protein band with an isoclectric point (pI) of $8.41 \pm 0.1$ in most $C F$ and in all heterozygous sera tested but not in most normal sera tested. Partial characterization of this protein indicated that it is a heat-labile $\gamma$-globulin. Thus, their findings indicated an electrophoretically identifiable protein with a pI similar to Schmoyer's electrofocused fraction reported earlier $(36,37)$, and suggested that this protein is analogous to the CF serum factor reported to be responsible for ciliary asynchrony. In 1975 Wilson et al. (53) reported the extension of this technique as "a standardized biophysical assay for the rapid detection of individuals homozygous or heterozygous for cystic fibrosis." They presented the details of the methodology and the results of analysis of a large number of serum samples. Identification of individuals homozygous or heterozygous for CF was based on the observation of a protein with a calculated pl of $8.46 \pm 0.05$. Furthermore, they postulated that this protein dissociates from IgG in 4 $M$ urea and has physicochemical properties similar to those found for a CF factor by other investigators.

In 1975 Altland $e t$ al. (2) stated, with respect to the banding pattern in the alkaline (pH 8-9) range reported by Wilson et al. (54), that they "could not clearly identify this variation even when isoclectric focusing was carried out with more spreading of the region of interest." However, they were able to demonstrate the presence of a factor in the serum of CF homozygotes and heterozygotes by a two-step electrophoretic technique, employing IEFAG to isolate IgG fractions and subsequent cathodic disc electrophoresis to allow fractionation partially on the basis of molecular weight. Thus, relatively small, cationic proteins could be separated from the larger $\gamma$-globulins. These investigators observed one or two protein bands in the dise gel (second step) 
when $20 \mu \mathrm{l}$ of sera from homozygotes or heterozygotes were applied in the first step (IEFAG); however, they observed no protein from the same amount of control sera, except in hemolyzed samples, which had a protein with electrophoretic mobility identical to the protein from CF sera. On the basis of the protein's cationic nature and relatively low molecular weight, Altland et al. (2) also suggested that this protein is similar to, if not identical with, the ciliary dyskinesia factor.

This communication relates our attempts to fractionate serum proteins by isoelectric focusing and electrophoresis and to detect a unique protein or proteins in CF homozygous and heterozygous sera. The IEFAG method specified by Wilson et al. (53) has been reproduced in our laboratory. The two-step IEFAG/ disc electrophoresis technique outlined by Altland et al. (2) has also been employed in our analyses. Furthermore, we have incorporated several methodologic improvements into the isoelectric focusing technique. These improvements have enabled us to demonstrate significantly enhanced resolution and a greater degree of heterogeneity of serum $\gamma$-globulins than other investigators have reported. The improved technique should increase the likelihood of detecting a CF-specific serum protein.

\section{MATERIALS AND METHODS}

CF patients were diagnosed on the basis of clinical history and an elevated chloride concentration in the sweat (20). Obligate heterozygotes were parents of these patients. Normal control subjects were clinically healthy volunteers with no known family history of CF. Several of the control subjects were orientals or American blacks, in whom the CF gene frequency is low $(24,29$, $49,56)$. Informed consent was obtained before subjects were admitted to the study.

Venous blood was collected and allowed to clot in glass tubes at $4^{\circ}$ for $2-4 \mathrm{hr}$. The blood was then centrifuged at $1,500 \times \mathrm{g}$ for $10 \mathrm{~min}$ at $4^{\circ}$. The serum was transferred to plastic tubes and either used fresh or frozen in aliquots at $-20^{\circ}$ or $-70^{\circ}$ for later analysis. The concentration of $\mathrm{IgG}$ was determined for some serum samples by single radial immunodiffusion (57) in order to standardize the volume of serum as specified by Wilson et al. (53).

Isoelectric focusing in thin layer polyacrylamide gel and the combined techniques of IEFAG/thin layer disc electrophoresis were performed in a plastic chamber with an aluminum cooling block $(58)$ through which coolant was circulated at $4^{\circ}$. The thin layer $(1.5 \mathrm{~mm}$ thick) polyacrylamide gels (59) were formed between two glass plates $(20 \times 20 \mathrm{~cm})$ by a common procedure $(47,50)$. Platinum ribbon electrodes $(60)$ and Ampholine carrier ampholytes (61) were used in the IEFAG technique. Ten to 12 samples, including at least 3 of each genotype (CF homozygote, $\mathrm{CF}$ heterozygote, normal control), were analyzed per gel to facilitate comparison of banding patterns. The $\mathrm{pH}$ gradients in IEFAG were measured at $8^{\circ}$ with flat membrane microclectrodes (62).

\section{IEFAG ACCORDING TO WILSON ET AL. (53)}

The biophysical assay of Wilson et al. was reproduced as described (53) with confirmation and elaboration of the methodology provided (51). The volume of serum samples analyzed by their technique was varied in order to have a constant amount of $\operatorname{IgG}(300 \mu \mathrm{g})$ in each sample, as specified (53). We have applied their method to the analysis of sera from $16 \mathrm{CF}$ patients, 13 obligate heterozygotes, and 14 normal control subjects.

\section{MODIFIED IEFAG (43)}

A variety of methodologic approaches to analytic isoelectric focusing were investigated in order to maximize the resolution of serum proteins, particularly the $\gamma$-globulins in the alkaline $\mathrm{pH}$ range. The details of our methods, a comparison with existing techniques for IEFAG, and the rationale for our approach to analytic isoelectric focusing will be presented elsewhere (43). In general, our attempts to detect a CF-specific protein in the isoelectric spectrum of serum proteins utilized three different $\mathrm{pH}$ gradient systems in IEFAG: (1) the standard broad range of $\mathrm{pH}$ $3.5-10,(2)$ a narrow range of $\mathrm{pH} 7-9$, and (3) a narrow range of $\mathrm{pH} 8.5-10.5$. In the broad range system $(\mathrm{pH} \mathrm{3.5-10),} \mathrm{the} \mathrm{gel}$ composition was as follows: $\mathrm{T}=3 \%$ and $\mathrm{C}=9 \%(63), 1.0 \%$ Ampholine carrier ampholytes (pH 3.5-10), 4.0 M urea, and $0.00005 \%$ riboflavin. Samples were pipetted onto $8-\mathrm{mm}$ wide pads of chromatography paper (64) placed near the middle of the gel. Electrofocusing was performed in a constant power mode during the initial stages of the run, after starting with a power supply voltage of $1000 \mathrm{~V}$ for an $18 \mathrm{~cm}$ electrode distance; the final potential was $2000 \mathrm{~V}$. The duration of the electrofocusing run was from 3.5-5.5 hr, depending on the portion of the isoelectric spectrum to be emphasized (43). After electrofocusing, the gels were fixed in a hot acid-alcohol solution and the ampholytes removed before staining with Coomassie brilliant blue (43).

The two alkaline range IEFAG systems had different gel compositions, but electrofocusing in these systems was based on the same principle. In the $\mathrm{pH}$ 7-9 system, the gel composition was as follows: $\mathrm{T}=3 \%$ and $\mathrm{C}=9 \%, 1.0 \%$ Ampholine carrier ampholytes $(0.1 \% \mathrm{pH} 3.5-10,0.2 \% \mathrm{pH} 5-7,0.7 \% \mathrm{pH} 7-9)$, $4.0 \mathrm{M}$ urea, $15 \%(\mathrm{v} / \mathrm{v})$ glycerol, and $0.00005 \%$ riboflavin. In the $\mathrm{pH} 8.5-10.5$ system, the gel composition was as follows: $\mathrm{T}=$ $3 \%$ and $\mathrm{C}=9 \%, 1.2 \%$ Ampholine carrier ampholytes $(0.2 \%$ pH $3.5-10,0.4 \%$ pH 7-9, $0.6 \%$ pH 9-11), $0.20 \%$ oxalic acid dihydrate (added to neutralize the solution to enable photopolymerization), $4.0 \mathrm{M}$ urea, $15 \%(\mathrm{v} / \mathrm{v})$ glycerol, and $0.00005 \%$ riboflavin. These latter gels were prefocused to disperse the oxalate ions toward the anode before ample application. In both alkaline range systems electrofocusing was performed in two stages. The first stage, during which the $\mathrm{pH}$ gradient began to form and proteins began to migrate either cathodally or anodally, was performed with the usual $18 \mathrm{~cm}$ electrode distance. For the second stage, the more acidic end of the gel was discarded and the anodic electrode was reapplied to the gel at a position in the gradient corresponding to $\mathrm{pH} 7.0$ (about $14 \mathrm{~cm}$ from the cathodic electrode) in the $\mathrm{pH} 7-9$ system or $\mathrm{pH} 8.5$ (about $10.5 \mathrm{~cm}$ from the cathodic electrode) in the $\mathrm{pH} 8.5-10.5$ system. This rearrangement of the anodic electrode allowed a more even conductance course between the electrodes and thus a higher potential drop across the alkaline range of the gradient (43). The total duration of the electrofocusing run, with potentials reaching $2000 \mathrm{~V}$, was $14 \mathrm{hr}$. The details of the methodology for focusing in the alkaline range will be presented elsewhere (43).

In addition to the general protocols outlined above, we employed variations in our analyses which should increase the possibility of detecting any consistent difference or differences among the genotypes. Gels of different $\mathrm{pH}$ gradients, with and without urea, were utilized. From $10-50 \mu \mathrm{l}$ of whole serum were analyzed. Alternatively, a volume of serum was used which contained $300 \mu \mathrm{g} \mathrm{IgG}$, as recommended by Wilson et al. (53). In some cases (as in the electrofocusing runs of shorter duration) the serum samples were pretreated with $4.0 \mathrm{M}$ urea for 4-24 hr. We have applied our various methods to the analysis of sera from $22 \mathrm{CF}$ patients, 23 obligate heterozygotes, and 21 normal control subjects.

\section{TWO-STEP IEFAG/THIN LAYER DISC ELECTROPHORESIS OF.} ALTLAND ET AL. (2)

The essential aspects of the two-step, one-dimensional technique as described by Altland $e t$ al. (2) were reproduced. The method of performing the first step (IEFAG to isolate IgG fractions) was varied. This preparative procedure was usually accomplished either in the manner specified by Altland et al. (2) or in a manner following our standard protocol as outlined above. Alternatively, the IEFAG step was performed as speci- 
fied by Wilson et al. (53), to simulate their conditions of sample treatment and fractionation.

The second step (thin layer disc electrophoresis) as outlined by Altland et al. (2) was used in some analyses, but modifications were later introduced to improve the resolution. The major modifications included the following: a stacking gel with the potassium-acetate buffer at $\mathrm{pH} 6.5$ (measured in the presence of $4.0 \mathrm{M}$ urea at $22^{\circ}$ ); a separating gel of $\mathrm{T}=15 \%, \mathrm{C}=5 \%$ with the potassium-acetate buffer at pH 5.0 (measured in the presence of $4.0 \mathrm{M}$ urea at $22^{\circ}$ ); rapid equilibration of the excised gel slab from IEFAG ( $\mathrm{pH} 7.5-9.5)$ in a buffer solution identical to that of the stacking gel; a 5.5-6.5-hr electrophoretic run at a constant current of $40 \mathrm{~mA}$; and staining of the separating gel by the method used in our IEFAG analyses (43).

We originally analyzed $20 \mu$ l of sera by this two-step technique, as suggested by Altland et al. (2). Since the degree of resolution in the first step (IEFAG) was not crucial, up to $200 \mu \mathrm{l}$ sera were analyzed in an effort to detect differences in protein bands present at low concentration. We have applied the twostep IEFAG/disc electrophoresis technique to the analysis of sera from 19 CF patients, 19 obligate heterozygotes, and 15 control subjects.

\section{RESULTS}

\section{IEFAG ACCORDING TO WILSON ET AL. (53)}

Based on the quantitation of $\mathrm{IgG}$ in the sera, the ranges of sample volumes (containing $300 \mu \mathrm{g} \mathrm{IgG}$ ) needed for analysis were as follows: $11-32 \mu \mathrm{l}$ (mean, 20) for $19 \mathrm{CF}, 14-33 \mu \mathrm{l}$ (mean, 25) for 20 heterozygote, and 13-44 $\mu$ l (mean, 27) for 21 normal control samples. These values fall within the ranges reported by Wilson et al. (53).

The protein banding patterns and the $\mathrm{pH}$ gradients obtained by the method of Wilson et al. (53) appeared similar to those shown in their illustrations. Among the $16 \mathrm{CF}, 13$ heterozygous, and 14 normal control sera analyzed, there was no band unique to the CF genotypes. However, the resolution was poor compared to the resolution obtained with our methods (see below and Fig. 6). We conclude that the method of Wilson et al. (53), as reproduced in our laboratory, is not capable of distinguishing genotypes.

\section{MODIFIED IEFAG (43)}

Generally 30 or $40 \mu \mathrm{l}$ sera were used in our IEFAG analyses. The concentration of $\mathrm{IgG}$ in some of the serum samples was determined for analysis by the method of Wilson et al. (53) or by

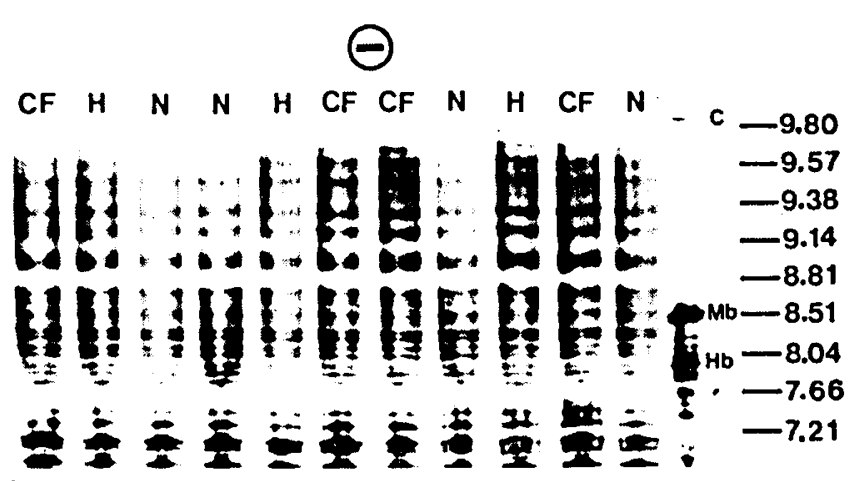

Fig. 1. Isoelectric focusing in polyacrylamide gel patterns of serum proteins using the broad range gradient ( $\mathrm{pH} 3.5-10)$. Only the alkaline end of the gel is shown. Sample volume was $30 \mu \mathrm{l}$. Serum samples are designated as: $\mathrm{CF}$ (cystic fibrosis), $\mathrm{H}$ (CF heterozygote), and $\mathrm{N}$ (normal control). Marker proteins are on right side: $\mathrm{Mb}$ (sperm whale myoglobin), $\mathrm{Hb}$ (human hemoglobin), $\mathrm{C}$ (horse heart cytochrome $c$ ). Urea concentration was $4.0 \mathrm{M}$. The measured $\mathrm{pH}$ gradient is shown to the side.

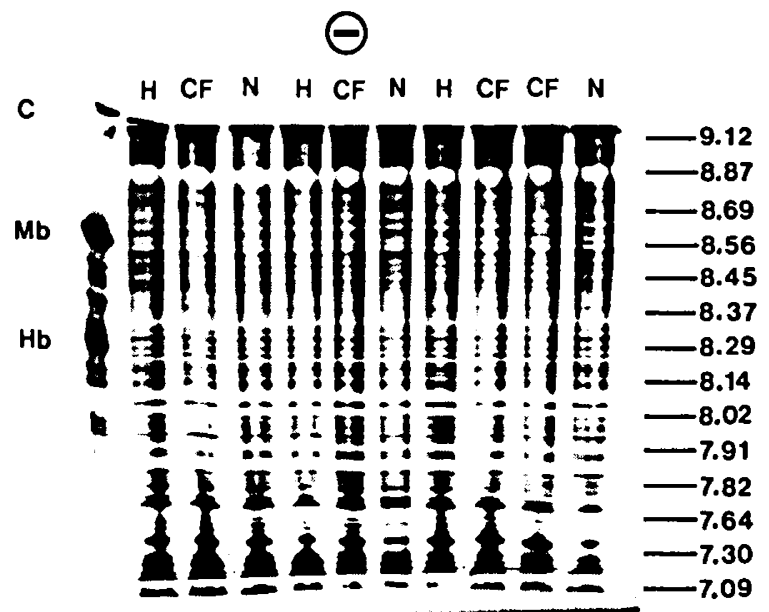

Fig. 2. Isoelectric focusing in polyacrylamide gel patterns of serum proteins usings a narrow range gradient ( $\mathrm{pH} 7-9$ ). Each sample contained $300 \mu \mathrm{g} \mathrm{IgG.} \mathrm{Serum} \mathrm{samples} \mathrm{and} \mathrm{marker} \mathrm{proteins} \mathrm{(on} \mathrm{left} \mathrm{side)} \mathrm{are}$ designated as in Figure 1. Urea concentration was $4.0 \mathrm{M}$. The measured $\mathrm{pH}$ gradient is shown to the side.

our method, and these determinations (see above) indicated that a sufficient volume of serum was analyzed to enable the detection of the "CF factor protein (CFP)" (53).

An example of IEFAG using the broad range gradient $(\mathrm{pH}$ $3.5-10$ ) is shown in Figure 1. Only the alkaline end of the gel is shown in this illustration, to emphasize the relevant section of the isoelectric spectrum. The banding pattern shows significant heterogeneity in this portion of the $\gamma$-globulin fraction. This pattern also indicates the presence of numerous protein bands both near the region of $\mathrm{pH}$ 8.4-8.5 (at which sperm whale myoglobin focuses in $4.0 \mathrm{M}$ urea) reported to contain the $\mathrm{CF}$ factor protein (53) and in the more alkaline region. In fact, the most alkaline serum proteins in the isoelectric spectrum are located at a pH near 10 (as measured in $4.0 \mathrm{M}$ urea). Thus, our method resolves numerous proteins in the far alkaline region of the gradient which are not apparent in the illustrations of Wilson et al. (53). Since this discrepancy, which is explainable in terms of the theoretic and practical aspects of IEFAG (see below), appeared consistently, we did not concentrate on detecting a difference near $\mathrm{pH} 8.4-8.5$ but considered the entire alkaline portion of the spectrum in our analyses.

Examples of IEFAG using the alkaline range gradients $(\mathrm{pH} 7-$ 9 and $\mathrm{pH} 8.5-10.5$ ) are illustrated in Figures 2 and 3, respectively. These methods significantly increase the resolving power in the alkaline range and thus enable the demonstration of an even greater degree of heterogeneity within this portion of the isoelectric spectrum of serum proteins. Also, using these methods of isoelectric focusing in two stages, larger sample volumes (50 $\mu \mathrm{l}$ or more) could be analyzed without engendering much distortion in the protein banding patterns, since the section of the gel containing the serum proteins in high concentration (i.e., albumin and $\alpha$-2-macroglobulin) is discarded.

These three methods and other variations in the IEFAG technique were applied to the analysis of $22 \mathrm{CF}, 23$ heterozygous, and 21 normal control sera. No consistent differences were apparent, despite a significant increase in the number of protein bands which were resolved.

\section{TWO-STEP IEFAG/THIN LAYER DISC ELECTROPHORESIS OF ALTLAND ET $A L$. (2)}

The combined technique of IEFAG/thin layer disc electrophoresis enabled the separation of low molecular weight proteins from serum $\mathrm{lgG}$. Thus, this approach should allow samples to be analyzed for the presence of small cationic proteins and should simplify the observation of the CF serum factor. 
An example of results with the two-step, one-dimensional technique of Altland $e t$ al. (2) is illustrated in Figure 4. This separating gel from the thin layer disc electrophoresis step demonstrates that at least one cationic protein of relatively low molecular weight can be fractionated from all serum samples control as well as CF sera (visibly unhemolyzed)-and that this protein has electrophoretic mobility identical to a larger amount of protein observed in hemolyzed samples. The modifications which we introduced in the disc technique separate these proteins more efficiently, as illustrated in Figure 5. The results indicate that several cationic proteins of low molecular weight can be fractionated from a portion of serum gamma globulins (approximately pl 7.5-9.5). Furthermore, benzidine staining indicates that some of these proteins contain heme.

$\mathrm{Up}$ to $200 \mu \mathrm{l}$ sera from $16 \mathrm{CF}, 17$ heterozygote, and 13 normal control samples were analyzed by either the technique of Altland et al. (2) or our modifications of this two-step technique. In addition, seven CF, five heterozygous, and five normal control sera were analyzed by the two-step techniques employing the IEFAG method of Wilson et al. (53). No consistently unique cationic protein of low molecular weight was observed in samples from CF patients or obligate heterozygotes.

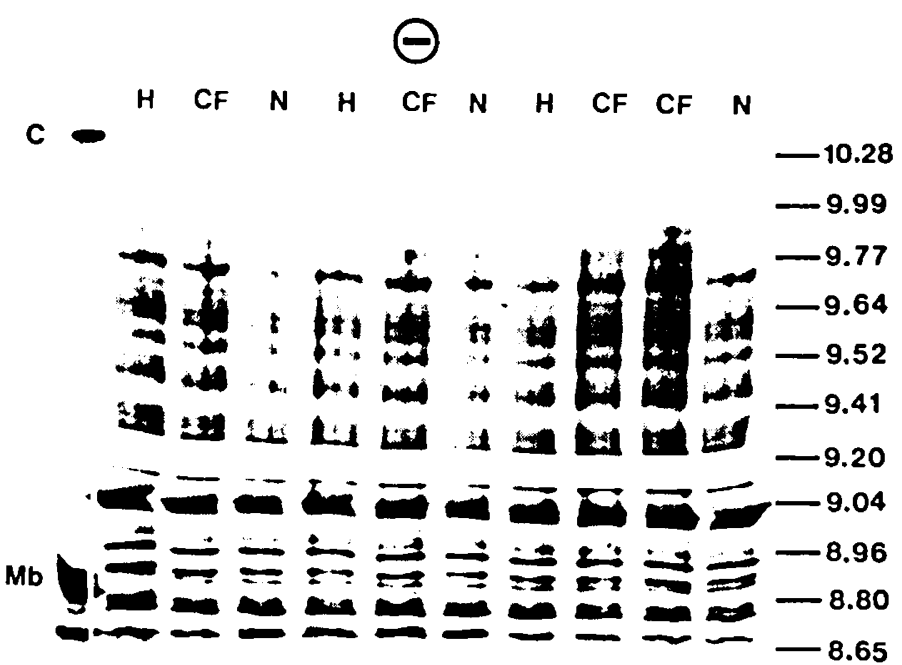

Fig. 3. Isoelectric focusing in polyacrylamide gel patterns of serum proteins using a narrow range gradient ( $\mathrm{pH} 8.5-10.5$ ). Each sample contained $300 \mu \mathrm{g} \mathrm{IgG.} \mathrm{Serum} \mathrm{samples} \mathrm{and} \mathrm{marker} \mathrm{proteins} \mathrm{are} \mathrm{designated}$ as in Figure 1. Urea concentration was $4.0 \mathrm{M}$. The measured pH gradient is shown to the side.

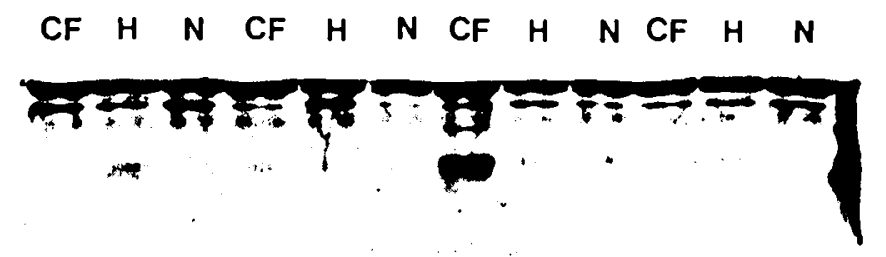

Fig. 4. Results of the two-step isoelectric focusing in polyacrylamide $\mathrm{gel} /$ thin layer disc electrophoresis, as outlined by Altland et al. (2). Only the thin layer separating the gel $(\mathrm{T}=7.5 \%)$ is shown. Sample volume was $50 \mu \mathrm{l}$. Serum samples are designated as in Figure 1. The CF sample in the center was hemolyzed to facilitate a comparison with visibly unhemolyzed samples. Marker proteins are on right side. Urea concentrations was $4.0 \mathrm{M}$.

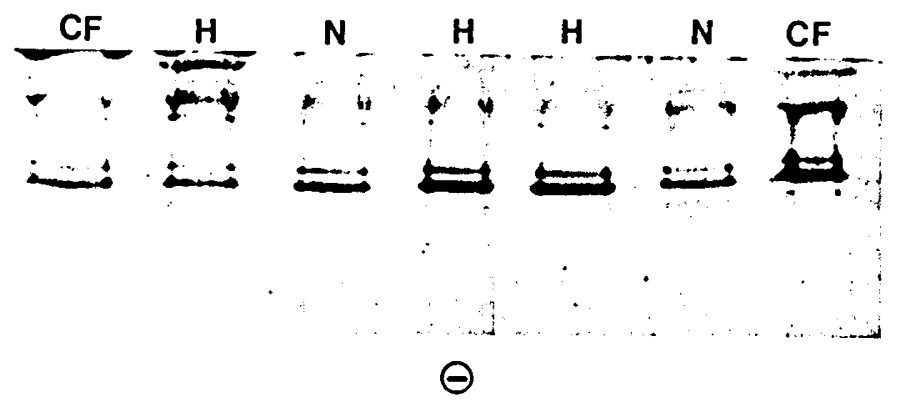

Fig. 5. Results of the two-step-isoelectric focusing in polyacrylamide $\mathrm{gcl} /$ thin layer disc electrophoresis, with our modifications. This illustration shows an enlargement of a portion of the thin layer separating gel $(\mathrm{T}=15 \%)$. Sample volume was $100 \mu \mathrm{l}$. Serum samples are designated as in Figure 1. All samples were visibly unhemolyzed. Urea concentration was $4.0 \mathrm{M}$.

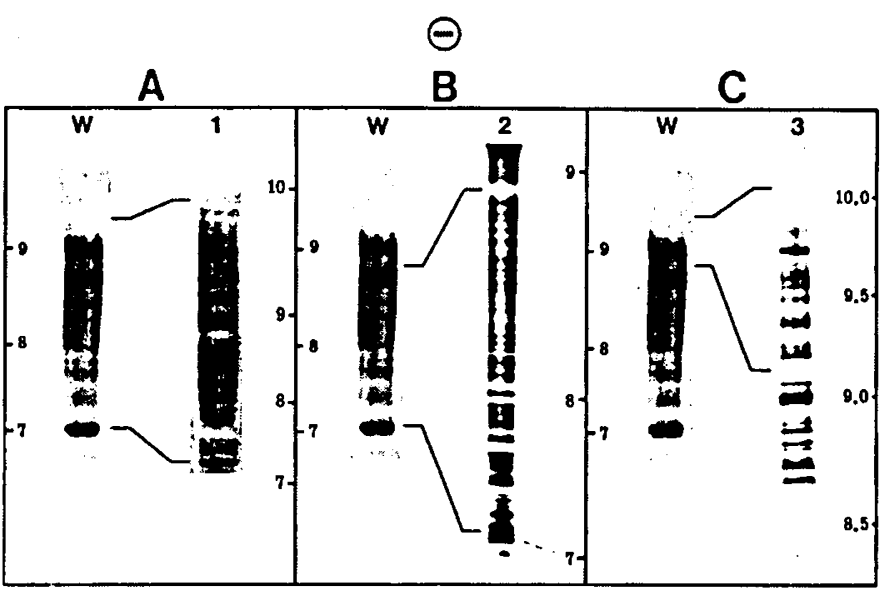

Fig. 6. Comparison of the four isoelectric focusing in polyacrylamide gel techniques showing serum protein banding patterns in the alkaline range. $A$ : comparison of patterns obtained by the method of Wilson et al. $(53)(W)$ and by our method using the broad range gradient of $\mathrm{pH} 3.5-$ $10(I) ; B$ : comparison of patterns obtained by the method of Wilson $e t$ al. (53) $(\mathrm{W})$ and by our method using the narrow range gradient of $\mathrm{pH}$ 7-9 (2); $C$ : comparison of patterns obtained by the method of Wilson et al. $(53)(W)$ and by our method using the narrow range gradient of $\mathrm{pH}$ 8.5-10.5 (3). Samples shown are identical (from a cystic fibrosis heterozygote), and each contained $300 \mu \mathrm{g} \mathrm{gG}$. Urea concentration in each case was $4.0 \mathrm{M}$. Approximate $\mathrm{pH}$ gradients are shown to the side of each sample. The expansions of the isoelectric spectra are indicated by the lines between each pair of banding patterns.

\section{COMPARISON OF IEFAG TECHNIQUES}

The improvement in the technique of analytic isoelectric focusing should be obvious from inspection of Figure 6 . This illustration shows a comparison of serum protein banding patterns in the alkaline range obtained by the four methods indicated. The method of Wilson et al. (53), using a pH 5-10 gradient, results in a paucity of single, identifiable protein bands. Although our method using the broad range gradient of $\mathrm{pH} 3.5-$ 10 shows significant improvement in the resolution and results in numerous identifiable bands, the methods which we have devised for focusing in the narrow gradients of $\mathrm{pH} 7-9$ and $\mathrm{pH} 8.5-$ 10.5 enhance the resolution even further. Consequently, the latter methods should be preferred for determining the banding pattern difference among individual sera with respect to $\gamma$ globulins in the alkaline range of the isoelectric spectrum. The improved resolution with the $\mathrm{pH} 7-9$ or $\mathrm{pH} 8.5-10.5$ system over that with our typical $\mathrm{pH} 3.5-10$ system is a consequence of the shallower $\mathrm{pH}$ gradient (a lower slope of the $\mathrm{pH}$ gradient, 
$d(\mathrm{pH}) / d \mathrm{X})(21)$ and the maintenance of a higher field strength (potential difference) exclusively across the alkaline range of the gradient (43). As indicated previously, even our method using the $\mathrm{pH}$ 3.5-10 system resolves numerous protein bands in the far alkaline region which are not resolved by the method of Wilson et al. (53), using the narrower pH 5-10 gradient. In the technique of Wilson et al. (53), focusing does not proceed to equilibrium, primarily because the polyacrylamide gels of $\mathrm{T}=5 \%$ exhibit a significant molecular sieving effect on the large $\gamma$ globulin molecules and also because an inadequate ficld strength is maintained across the alkaline region of the gel (43).

\section{DISCUSSION}

This study involved electrophoretic analysis in an attempt to detect a CF serum factor. The "biophysical assay" of Wilson $e$ al. (53) and the "non-biological technique" of Altland et al. (2) were reproduced. In addition, an extensive investigation using our own techniques for analytic isoelectric focusing and disc electrophoresis was undertaken. Our approach, employing different electrophoretic techniques and varying the conditions of sample analysis, should increase the likelihood of detecting a protein or proteins specific for the CF genotypes. Many of the serum samples in our study were analyzed by more than one technique. Thus, in many cases, the same sample was analyzed by the method of Wilson et al. (53), by the method of Altland et al. (2), and by our various methods. Furthermore, in some cases, different serum samples were obtained from the same individual in an attempt to determine any intraindividual variation. Despite the many variations in our approach, no consistently unique protein was observed in CF or heterozygous sera.

The "standardized biophysical assay" of Wilson et al. (53), as reproduced in our laboratory, did not enable the detection of a

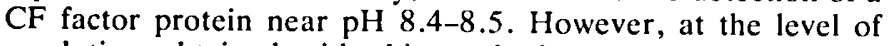
resolution obtained with this method, nuances in technique (e.g., the use of different batches of Ampholine chemicals) could conceivably obscure the band which may represent a protein unique to $C F$ and heterozygous sera. Consequently, the IEFAG technique was improved to an extent capable of demonstrating striking heterogeneity in serum proteins (43). Despite the significant increase in the number of bands resolved by our methods, neither a difference at $\mathrm{pH}$ 8.4-8.5 nor other differences throughout the alkaline $\mathrm{pH}$ range could be detected consistently in the $\mathrm{CF}$ and heterozygous sera. However, since some unknown factor in the technique of Wilson et al. (53) might result in the "production" of the CF protein factor at $\mathrm{pH} 8.4-8.5$, our investigations have included the use of their IEFAG method in the two-step IEFAG/disc electrophoresis technique. This combination of techniques also did not result in the detection of consistent differences. Thus, our efforts indicate, contrary to the implication by Wilson et al. (53), that a low molecular weight, cationic CF serum protein is not readily demonstrable. Furthermore, our IEFAG analyses did not support the usefulness of the "B, C, and D bands" reported by Wilson et al. (53) in distinguishing between $C F$ and heterozygous sera. In view of the complexity of the banding pattern in this region of the spectrum $(\mathrm{pH} 7.5-8.5)$, a real difference relative to one of only three bands would appear to be unlikely.

The two-step method of Altland et al. (2) might be invaluable if the CF serum factor were a low molecular weight, cationic protein. As indicated previously, the application of this technique would simplify the detection of such a protein band if the resolution at the IEFAG step were inadequate. Our investigations using the "non-biological technique" of Altland et al. (2) indicated that at least one small, cationic protein could be fractionated from all serum samples. Improvements in the method of disc electrophoresis resulted in the observation of numerous bands from some samples and of differences among the samples, but no protein band unique to the CF genotypes was observed. Furthermore, the major cationic protein(s) fractionated from come sera in the second step appeared to correlate with the presence of heme in the band(s), although these serum samples were visibly unhemolyzed. In their report, Altland et al. (2) stated that different serum samples from the same "factorpositive individual" showed "quantitative variation from zero to intensive even in $10 \mu \mathrm{l}$ samples," with respect to the "CF factor band" which they observed. Some intraindividual variation was also noted in some of our samples, but, more importantly, the relevant band was intense only in those samples which were slightly hemolyzed. (Some liberation of hemoglobin from erythrocytes may be unavoidable when withdrawing and processing blood.) In view of the great quantitative variation noted by Altland $e t$ al. (2) and their application of the assay to only a few serum samples, their demonstration of a difference between $\mathrm{CF}$ and control sera may have resulted from a fortuitous difference in serum hemoglobin rather than from the actual observation of a CF serum factor.

Recently, a preliminary report of this investigation appeared (42), together with a response by Wilson et al. (55). In addition, Smith et al. (39) reported the inability to reproduce the results of Wilson et al. $(53,54)$ and Altland et al. (2). Although we have not seen their response (52) to the latter report (39) at the time of this writing, Wilson et al. (55) related that they had suggested (52) several possible reasons for the conflicting results we initially reported (41), and those of Smith et al. (39). Also, Wilson et al. (55) stated that additional details were provided (52) concerning their methodology and the reagents employed. Presumably, their additional details will complete a description of the incomplete methodology presented earlier $(53,54)$.

In their response (55) to our preliminary note (42), Wilson et al. (55) discussed several points concerning their method which allegedly presented problems for us and which may present problems for other investigators attempting to use analytic isoelectric focusing to detect "cystic fibrosis protein (CFP)." Neither space nor discretion will permit a complete response to all of the remarks made by Wilson et al. (55) concerning our attempts to reproduce their method. However, it is apparent that our procedures as reported here followed their guidelines specified originally (53) and also most of the new specifications (55) for their erstwhile "standardized" assay. Thus, their procedures (53) of sample collection and quantitation of $\mathrm{IgG}$ have been followed. Concerning the localization of "CFP" on the gel, our criteria have been more flexible than their requirement for finding a specific difference at a certain $\mathrm{pH}$ or a certain distance from the anode. As emphasized in the present report, we did not concentrate on detecting a difference near $\mathrm{pH} 8.4-8.5$, but considered the entire alkaline portion of the spectrum in our analyses. In fact, this approach was necessary in view of the differences in $\mathrm{pH}$ measurements and corresponding band locations obtained with our improved techniques (see Figure 6).

Although we are aware of potential problems in the precise measurement of $\mathrm{pH}$ gradients in analytic isoelectric focusing, we are also confident that the measurements obtained from our modified methods reflect accurate values for the pl's of the relevant proteins. We base this conclusion on the pl's of a specific marker protein (sperm whale myoglobin) and the most cationic serum proteins (those with the highest pI's). Several investigations on isoclectric focusing of sperm whale myoglobin have demonstrated a $\mathrm{pl}$ of $8.1 \pm 0.1$ for the major component of this protein in the ferric state $(25,28,31-35)$. We also have obtained this value for our preparation of sperm whale myoglobin when it was focused in the absence of urea. It has been realized for some time that urea increases the $\mathrm{pK}$ values of dissociable groups and the measured $\mathrm{pH}$ of aqueous solutions, presumably by reducing the activity of hydrogen ions (12), and the fact that urea also increases the apparent $\mathrm{pH}$ of carrier ampholyte solutions and thus the measured pI in isoelectric focusing has been discussed by several investigators $(23,35,40$, $44,45)$. Although the degree of elevation of $\mathrm{pH}$ will depend on the urea concentration and the buffering system, our studies and the reports in the literature $(23,35,40,44,45)$ indicate that the measured $\mathrm{pI}$ of a carrier ampholyte in $4.0 \mathrm{M}$ urea would be 
increased by $0.3 \pm 0.1 \mathrm{pH}$ units. Thus the $\mathrm{pI}$ of the major component of sperm whale myoglobin (ferric) measured in the presence of $4.0 \mathrm{M}$ urea would be $8.4 \pm 0.2$. As illustrated in Figures 1, 2, and 3 of this report, our measured pI for this protein, using three different $\mathrm{pH}$ gradients, agrees well with the expected values based on reports in the literature $(25,28,31$ $35)$. Concerning the most cationic proteins in serum, the true $\mathrm{pl}$ 's of these proteins have not been realized, primarily because of the heretofore persistent problems in alkaline range isoelectric focusing in polyacrylamide gels $(43,48)$. We have been able to solve many of these problems, thus accounting for our unprecedented degree of resolution of serum proteins with high pI's. As suggested earlier in this report and detailed elsewhere (43), our approach to isoelectric focusing in the alkaline range is based on the theoretical aspects of resolving power in natural (ampholyte) $\mathrm{pH}$ gradients, the physical properties of commercial ampholytes in an electric field, and the physicochemical properties of serum proteins which focus in the alkaline range. The exploitation of these aspects is requisite for the near equilibrium focusing of cationic serum proteins which is achieved in our system and which has not been accomplished by other investigators to date. However, several published references to isoelectric focusing of serum proteins in sucrose density gradients have provided evidence that some major serum proteins focus at $\mathrm{pH} 9.5$ or above in the absence of urea $(6,22,36,37,46,50)$. The measured $\mathrm{pI}$ of these proteins in the presence of $4.0 \mathrm{M}$ urea would be 9.8 or above. Thus our illustrations showing bands at $\mathrm{pH} 9.8$ or higher are entirely credible, contrary to the implications of Wilson et al. (55).

In addition, Wilson et al. (55) stated that a major problem might have been our failure to use the unique apparatus employed by Awdeh et al. (3). However, the use or importance of this apparatus was neither stated nor emphasized in the original reports by Wilson et al. $(53,54)$, and they are now employing (55) a different apparatus, the LKB Multiphor. Thus it would appear to be unlikely that our use of the Brinkman electrofocusing apparatus precludes the detection of any "cystic fibrosis factor." With respect to their results using the LKB Multiphor apparatus presented in the response of Wilson et al. (55) to our preliminary report $(42)$, it should be noted that they have also altered their "standardized biophysical assay" by employing a different $\mathrm{pH}$ gradient and a different voltage sequence. Thus, these aspects of their "standardized" assay may also not be essential for detecting "CFP," contrary to their communication to us (51) or the implication in their response (55). Lastly, it appears that Wilson et al. (55) have been able to improve their patterns shown earlier (53) by modifying their method. Their banding patterns have now improved sufficiently to enable a comparison with ours presented earlier (42) and in the present communication. A major hallmark of the alkaline isoelectric spectrum of serum proteins is the blank space at about $\mathrm{pH} 9.0$ in our illustrations (Figures 1, 2, and 3). This space is also apparent in the illustration in the response of Wilson et al. (55), but appears at about $\mathrm{pH} 7.5$ in their publication (primarily because focusing has not approached equilibrium). However, these areas are identical with respect to the protein banding patterns, and some appreciation for this may be obtained by inspection of Figure 6 in this report, in which we compare our three modified methods to our reproduction of the first "standardized assay" presented by Wilson et al. (53). The number of countable bands cathodal to this space will attest to the relative levels of experience and expertise which Wilson et al. and we have achieved in analytic isoelectric focusing.

Clearly, the results of our extensive investigation do not confirm the findings of Wilson et al. (53) or Altland et al. (2). If a protein factor can be readily demonstrated in CF sera by electrophoretic analysis, several possibilities may account for our findings: differences in technique and/or the handling of sera, gross variation in the concentration of any CF factor(s), the presence of the same (but physiologically inactive) factor(s) in control sera at a generally lower but variable concentration, or genetic heter- ogeneity in CF. In an attempt to determine the reasons for differences in results between the laboratories, we have communicated with both Wilson and Altland $(1,51)$. Altland (1) has indicated to us that his technique will require further modification before a CF serum factor can be reproducibly demonstrated. A collaborative study with the Wilson group would be particularly valuable in resolving the differences. Our efforts to establish such a study have not been successful to date. In the future, cooperation between the involved laboratories may be necessary for the proper evaluation of these techniques with respect to $\mathrm{CF}$. $\zeta$

\section{CONCLUSION}

A considerable amount of indirect evidence indicates that fluids from CF patients and obligate heterozygotes contain a factor or factors which may be relevant to the pathophysiology of $\mathrm{CF}$. Much of the evidence indicates that the factor is a low molecular weight, cationic protein which in serum is associated with IgG. Detection of such a protein factor by electrophoretic analysis should be possible, and two studies reported in the literature, each employing a different electrophoretic technique, have claimed identification of a serum protein unique to $\mathrm{CF}$ genotypes.

Our study reproduced the techniques of Wilson et al. (53) (isoclectric focusing in polyacrylamide gel) and Altland et al. (2) (IEFAG/thin layer disc electrophoresis) in an attempt to detect a $C F$ factor in serum. In addition, several modifications were incorporated into these techniques in order to enhance the resolution, and variations in the conditions of sample analysis were employed in order to increase the likelihood of detecting a protein or proteins specific for the CF genotypes. Our modified IEFAG method enabled the demonstration of striking heterogeneity in serum $\gamma$-globulins, but no consistent differences in banding patterns between CF or heterozygous sera and control sera have been apparent. Our modified IEFAG/thin layer disc electrophoresis system indicated that several cationic, low molecular weight proteins can be fractionated from all serum samples, but no consistently unique protein has been observed in CF or heterozygous sera. Although several possibilities may account for the discrepancy between our results and those reported in the literature, our present conclusion is that the CF serum factor(s) cannot be readily demonstrated by the electrophoretic techniques described or our improvements thereof.

\section{REFERENCES AND NOTES}

1. Altland, K.: Personal communication.

2. Altland, K., Schmidt, S. R., Kaiser, G., and Knoche, W.: Demonstration of a factor in the serum of homozygotes and heterozygotes for cystic fibrosis by a non-biological technique. Humangenetik, 28: 207 (1975).

3. Awdeh, Z. L., Williamson, A. R., and Askonas, B. A.: Isoelectric focusing in polyacrylamide gel and its application to immunoglobulins. Nature, 219: 66 (1968).

4. Barnett, D. R., Kurosky, A., Bowman, B. H., and Barranco, S. C.: Loss of the ciliary inhibitory effect of the cystic fibrosis factor following proteolytic digestion and heat denaturation. Tex. Rep. Biol. Med., 31: 697 (1973).

5. Barnett, K. R., Kurosky, A., Bowman, B. H., Hutchison, H. T., Schmoyer, I., and Carson, S. D.: Cystic fibrosis: Molecular weight estimation of the ciliary inhibitor. Tex. Rep. Biol. Med., 3l: 703 (1973).

6. Barnett, K. R., Schanfield, M. S., McCombs, M. L., and Bowman, B. H.: Isoelectric focusing and IgG allotyping of the serum factor containing the cystic fibrosis ciliary inhibitor. Tex. Rep. Biol. Med., 31: 709 (1973).

7. Beratis, N. G., Conover, J. H., Conod, E. J., Bonforte, R. J., and Hirschhorn, K.: Studies on ciliary dyskinesia factor in cystic fibrosis. III. Skin fibroblasts and cultured amniotic fluid cells. Pediat. Res. 7: 958 (1973).

8. Bowman, B. H.: Introduction: Progress in research toward identifying the basic defect in cystic fibrosis. Tex. Rep. Biol. Med. 31: 611 (1973)

9. Bowman, B. H., Hirschhorn, K., and Bearn, A. G.: Bioassays of cystic fibrosis factor. Lancet, $i: 404$ (1974).

10. Bowman, B. H., Lankford, B. J., Fuller, G. M., Carson, S. D., Kurosky, A., and Barnett, D. R.: Cystic fibrosis: The ciliary inhibitor is a small polypeptide associated with immunoglobulin $\mathrm{G}$. Biochem. Biophys. Res. Commun., 64: 1310 (1975).

11. Bowman, B. H., and Mangos, J. A.: Current concepts in genetics: Cystic fibrosis. N. Engl. J. Med. 294: 937 (1976)

12. Bull, H. B., Breese, K., Ferguson, G. L., and Swenson, C. A.: The pH of urea 
solutions. Arch. Biochem. Biophys. 104: 297 (1964).

13. Committee for a Study for Evaluation of Testing for Cystic Fibrosis: Report of the Committee for a Study for Evaluation of Testing for Cystic Fibrosis. J. Pediat. 88: 711 (1976).

14. Conneally, P. M., Merritt, A. D., and Yu, P.: Cystic fibrosis: Population genetics. Tex. Rep. Biol. Med. 31: 639 (1973)

15. Conover, J. H., Beratis, N. G., Conod, E. J., Ainbender, E., and Hirschhorn, K.: Studies on ciliary dyskinesia factor in cystic fibrosis. II. Short term leukocyte cultures and long term lymphoid lines. Pediat. Res. 7: 224 (1973).

16. Crow, J. F.: Problems of ascertainment in the analysis of family data. In: J. V. Neel, M. W. Shaw, and W. J. Schull: United States Public Health Service Publication, No. 1163, p. 23 (1965)

17. Danes, B. S., Litwin, S. D., Hutteroth, T. H., Cleve, H., Bearn, A. G.: Characterization of cystic fibrosis factor and its interaction with human immunoglobulin. J. Exp. Med. 137: 1538 (1973).

18. Danks, D. M., Allan, J., and Anderson, C. M.: A genetic study of fibrocystic disease of the pancreas. Ann. Hum. Genet. 28: 323 (1965).

19. di Sant'Agnese, P. A., and Davis, P. B: Research in cystic fibrosis. N. Engl. J. Med., 295: 481, 534, 597 (1976).

20. Gibson, L. E., and Cooke, R. E.: A test for concentration of electrolytes in sweat in cystic fibrosis of the pancreas utilizing pilocarpine by iontophoresis. Pediatrics, 23: 545 (1959).

21. Haglund, $\mathrm{H}$.: Isoelectric focusing in $\mathrm{pH}$ gradients $-\mathrm{A}$ technique for fractionation and characterization of ampholytes. Methods Biochem. Anal. 19: (1971).

22. Howard, A., and Virella, G.: The separation of pooled human IgG into fractions by isoelectric focusing, and their electrophoretic and immunological properties. In: H. Peeters: Protides of the Biological Fluids, Vol. 17, p. 449 (Pergamon Press, New York, 1969).

23. Josephsen, R. V., Maheswaran, S. K., Mori, C. V., Jenness, R., and Lindorfer, R. K.: Effect of urea on pI's of ampholytes and casein in isoelectric focusing. Anal. Biochem. 40: 476 (1971).

24. Kulczcki, L. L., Guin, G. H., and Mann, N.: Cystic fibrosis in Negro children: Results of a search. Clin. Pediat., 3: 692 (1964).

25. LaGow, J., and Parkhurst, L. J.: Kinetics of carbon monoxide and oxygen binding for eight electrophoretic components of sperm-whale myoglobin. Biochem. 11: 4520 (1972).

26. Lobeck, C. C.: Cystic fibrosis. In: J. B. Stanbury, F. B. Wyngaarden, and D. S. Frederickson: The Metabolic Basis of Inherited Disease, Ed. 3 (McGrawHill, New York, 1972).

27. McCombs, M. L.: Research in cystic fibrosis: A review. Tex. Rep. Biol. Med. 31: 615 (1973)

28. Nakhleh, E. T., Abu Samra, S., and Awdeh, Z. L.: Isoelectric focusing of phenanthroline iron complexes and their possible use as $\mathrm{pH}$ markers. Anal. Biochem. 49: 218 (1972).

29. Oppenheimer, E. H., and Esterly, J. R.: Cystic fibrosis in non-Caucasian patients. Pediatrics, 42: 547 (1968)

30. Polley, M. J., and Bearn, A. G.: Cystic fibrosis: Current concepts. J. Med. Genet., 11: 249 (1974).

31. Radola, B. J.: Analytical and preparative isoclectric focusing of proteins in Sephadex and Bio-Gel layers. In: H. Peeters: Protides of the Biological Fluids, Vol. 18, p. 487 (Pergamon Press, New York, 1970).

32. Radola, B. J.: Isoelectric focusing in layers of granulated gels. I. Thin-layer isoelectric focusing of proteins. Biochim. Biophys. Acta 295: 412 (1973).

33. Radola, B. J.: Analytical and preparative isoelectric focusing in gel-stabilized layers. Ann. N. Y. Acad. Sci. 209: 127 (1973).

34. Radola, B. J.: Isoelectric focusing in layers of granulated gels. II. Preparative isoelectric focusing. Biochim. Biophys. Acta 386: 181 (1974).

35. Salaman, M. R., and Williamson, A. R.: Isoelectric focusing of proteins in the native and denatured states: anomalous behavior of plasma albumin. Biochem. J. 122: 93 (1971).

36. Schmoyer, I. R., Brooks, S. P., and Fischer, J. F.: Isolation and characterization of a ciliary dyskinetic factor from cystic fibrosis heterozygous serum. Life Sci. 11: 1037 (1972).

37. Schmoyer, I. R., Fischer, J. F., and Brooks, S. P.: Fractionation of oyster cilia inhibitor from cystic fibrosis heterozygote serum. Biochem. Biophys. Res. Commun. 46: 1923 (1972)

38. Shwachman, H.: Changing concepts in cystic fibrosis. Hosp. Prac. 9: 143 (1974).

39. Smith, Q. T., Hamilton, M. J., and Shapiro, B. L.: Letter to the Editor. Pediat. Res., 10: 999 (1976).

40. Smyth, C. J., and Arbuthnott, J. P.: Properties of Clostridium perfringes (Welchii) Type-A $\alpha$-toxin (phospholipase C) purified by electrofocusing. J. Gen. Microbiol., 7: 41 (1974).
41. Thomas, J. M., Merritt, A. D., and Hodes, M. E.: Electrophoretic analysis of serum proteins in cystic fibrosis. In: Cystic Fibrosis Club Abstracts, Seventeenth Annual Meeting, p. 19 (Cystic Fibrosis Foundation, Atlanta, 1976).

42. Thomas, J. M., Merritt, A. D., and Hodes, M. E.: Letter to the Editor: Electrophoretic analysis of serum proteins in cystic fibrosis. Pediat. Res., 11: 138 (1977)

43. Thomas, J. M., and Hodes, M. E.: In preparation.

44. Ui, N.: Isoelectric points and conformation of proteins. I. Effect of urea on the behavior of some proteins in isoelectric focusing. Biochem. Biophys. Acta, 229: 567 (1971).

45. Ui, N.: Conformational studies on proteins by isoelectric focusing. Ann. N. Y. Acad. Sci. 209: 198 (1973).

46. Valmet, E.: Demonstration of the microheterogeneity of human serum gamma-globulin by isoelectric focusing. Sci. Tools 15: 8 (1968).

47. Vesterberg, O.: Isoelectric focusing of proteins in polyacrylamide gels. Biochim. Biophys. Acta 257: 11 (1972).

48. Vesterberg, O.: Some aspects of isoelectric focusing in polyacrylamide gel. In: J. P. Arbuthnott and J. A. Beeley: Isoelectric Focusing (Butterworths, London, 1975).

49. Wang, C. I., Sumi, W. T., Stanton, R., Kwok, S., and Yamazaki, J. N.: Cystic fibrosis in an Oriental child. N. Engl. J. Med., 279: 1216 (1968).

50. Williamson, A. R.: Isoelectric focusing of immunoglobulins. In: D. M. Weir: Handbook of Experimental Immunology, Ed. 2 (Blackwell Scientific Publishers, New York, 1973).

51. Wilson, G. B.: Personal communication.

52. Wilson, G. B., Arnaud, P., MOnsher, M. T., and Fundenberg, H.: Letter to to the Editor: Detection of cystic fibrosis protein by electrofocusing. Pediat. Res.. 10: 1001 (1976).

53. Wilson, G. B., Fudenberg, H. H., and Jahn, T. L.: Studies on cystic fibrosis using isoelectric focusing. I. An assay for detection of cystic fibrosis homozygotes and heterozygote carriers from serum. Pediat. Res., 9: 635 (1975).

54. Wilson, G. B., Jahn, T. L., and Fonseca, J. R. Demonstration of serum protein differences in cystic fibrosis by isoelectric focusing in thin-layer polyacrylamide gels. Clin. Chim. Acta, 49: 79 (1973).

55. Wilson, G. B., Monsher, M. T., and Fudenberg, H.: Letter to the Editor: Additional notes on the use of analytical isoelectric focusing for the detection of cystic fibrosis protein in serum. Pediat. Res., 11: 139 (1977).

56. Wright, S. W., and Morton, N. E.: Genetic studies on cystic fibrosis in Hawaii. Amer. J. Hum. Genet. 20: 157 (1968).

57. Immunoglobulin $\mathrm{G}$ (IgG) Test Kit for the Quantitation of Human IgG by the Technique of Single Radial Immunodiffusion. Meloy Laboratories, Inc., Springfield, Virginia.

58. Desaga/Brinkman TLE Double Chamber. Brinkman Instruments, Westbury, New York.

59. Acrylamide and $N, N^{\prime}$-methylenebisacrylamide were either electrophoresis grade or a standard grade which was recrystallized according to Loening, $U$. E.: The fractionation of high molecular-weight ribonucleic acid by polyacrylamide gel electrophoresis. Biochem. J., 102: 251 (1967). Eastman Organic Chemicals, Rochester, N. Y.

60. Desaga/Brinkman platinum ribbon electrodes. Brinkman Instruments, Westbury, New York.

61. LKB Ampholine carrier ampholytes. LKB Produkter, A. B. Stockholm, Brooma, Sweden.

62. Desaga/Brinkman $\mathrm{pH}$ measuring accessories. Brinkman Instruments, Westbury, N. Y.

63. $\% \mathrm{~T}=$ grams of acrylamide + grams of bisacrylamide per $\mathrm{dl}$ solution; $\% \mathrm{C}=$ $100 \times$ grams of bisacrylamide per $\mathrm{dl}$ per \%T. Nomenclature according to Hjerten, S.: "Molecular sieve" chromatography on polyacrylamide gels, prepared according to a simplified method. Arch. Biochem. Biophys. Suppl., 1: 147 (1962)

64. S\&S No. 470 A-C "ash-low" filter paper. Schleicher \& Schuell, Inc., Keene, N. H.

65. The assistance of Debbie Tabakin and Alice Pigg in collecting the specimens is gratefully acknowledged.

66. John M. Thomas was supported by National Institutes of Health Training Grant PHS GM 1056.

67. This is Publication no. 76-25 from the Department of Medical Genetics and was supported in part by the Indiana University Human Genetics Center, PHS GM 21054

68. Requests for reprints should be addressed to: M. E. Hodes, M.D., Department of Medical Genetics, Indiana University School of Medicine, 1100 West Michigan St., Riley Research 241, Indianapolis, Indiana 46202 (USA).

69. Received for publication December 2, 1977

70. Accepted for publication February 23, 1977 